\title{
Reseña: De amor y odio: vida matrimonial, conflicto e intimidad en el sur andino colonial, 1750-1825 de Nicholas A. Robins
}

Luis Bustamante

doi: $10.46476 /$ ra.vi1.46

Nicholas A. Robins. De amor y odio: vida matrimonial, conflicto e intimidad en el sur andino colonial, 1750-1825. Lima: Instituto de Estudios Peruanos, 2019.

Sorprende la reciente publicación de Nicholas Robins, básicamente por su trayectoria historiográfica más ligada al estudio de los movimientos sociales y a temas medioambientales andinos. Pero sorprende más por la calidad de su contenido. Dedicada a examinar el matrimonio, la vida privada y cotidiana de Charcas virreinal en el marco del reformismo borbónico, la crisis colonial y la independencia, el libro del profesor Robins se suma a la aún exigua lista de materiales consagrados a estos tópicos en el concierto de las naciones andinas.

En el libro podemos encontrar, en principio, una perspectiva estructural que sirve para describir ciertas prácticas y costumbres que eran más frecuentes de lo imaginado. En teoría, el matrimonio canónico - que tenía funciones claramente delimitadas y estereotipadas, explicadas desde el patriarcado y el honor- debía ser el único marco de las relaciones de pareja, incluyendo el sexo. Si, además, aquel surgía supuestamente del libre consentimiento (y presuntamente del amor) y la moral matrimonial, estaba estrechamente vigilada, la unión conyugal no debía presentar mayores conflictos y si los hubiere debían ser solucionados al interior del 
hogar. Pero la realidad era otra, como lo demuestran los numerosos matrimonios organizados por los padres (o tutores), incluyendo aquellos surgidos de la instigación o imposición, los nutridos maridos ausentes, las relaciones ilícitas de larga duración (amancebamientos), la ilegitimidad, las promesas matrimoniales incumplidas, la bigamia, la sevicia, entre otros excesos u «ofensas» a Dios.

Esta es la armazón que sirve al autor para aterrizar luego en la coyuntura, es decir, en el terreno del reformismo borbónico y sus políticas, y demostrar que el programa monárquico no fue solo administrativo, económico o político. El despotismo ilustrado español buscó igualmente enfrentar esta realidad disfuncional, caracterizada por una evidente distancia entre lo que se esperaba y lo que acontecía. Estamos, pues, ante un programa destinado a combatir también los desórdenes domésticos, las intemperancias de la vida marital; por lo mismo, un programa que buscó controlar el matrimonio y la conflictividad derivada de las relaciones conyugales. Y este es uno de los méritos del libro del profesor Robins: examinar la implementación de las políticas tardías del imperio español, referidas al matrimonio y la intimidad, así como su impacto en la gente y la manera cómo fueron resistidas (o usadas). Con el añadido de haber empleado casos provenientes de la documentación contenciosa que ilustran el quehacer cotidiano de la población.

Lo que el libro nos demuestra, a este respecto, es que la modernización borbónica fracasó, pues muchos de los problemas mencionados no solo no desaparecieron, sino que aumentaron y se visibilizaron. Los resultados son irónicamente contradictorios: debía ponerse fin a las uniones libres, pero estas abundaban y no siempre eran denunciadas; debían evitarse los matrimonios desiguales, pero la norma en cuestión, la Pragmática Sanción para evitar el abuso de contraer matrimonios desiguales (1776), ocasionó un cúmulo de juicios por «oposición matrimonial», estimulando lo que no se pretendía, la litigiosidad, a la vez que los matrimonios clandestinos terminaron multiplicándose. Por otra parte, debían controlarse los adulterios y la sevicia, pero los procesos judiciales alusivos a estos y otros temas concurrentes, que daban mérito a querellas maritales judicializadas, se incrementaron. En general, como afirma el autor, «los esfuerzos destinados a reafirmar el patriarcado en Charcas de la colonia tardía en realidad exacerbaron las tendencias que pretendían revertir».

Al mismo tiempo, el trabajo de Robins nos muestra una realidad que trasciende el ámbito de lo doméstico y lo íntimo o, en todo caso, lo subvierte. En efecto, las mujeres, el epítome de la domesticidad, eran más independientes de lo que parecía; en tal sentido, no eran pocas las que trabajaban, litigaban, negociaban y hasta amaban fuera de los marcos de la casa; y ello no se limitaba a las viudas, pues había muchas separadas «de facto», así como «solteras», aunque esta libertad fue, realmente, relativa, dado el peso e importancia del patriarcado (y del honor). De otra parte, los testigos de los conflictos judicializados eran, muchas veces, los 
esclavos, los sirvientes, los vecinos y hasta los transeúntes; todos ellos «oían», «veían», «comprobaban», «intervenían» y pertenecían a diversos segmentos sociales y étnicos. Una pregunta salta a la vista: ¿había verdadera intimidad, si tomamos en cuenta estas (y otras) consideraciones? Por ejemplo, no era extraño que la vivienda popular sea una prolongación del taller o que la casa-habitación se ubique dentro de una vecindad o callejón en donde la fragilidad de las paredes permitía escuchar al propietario o inquilino próximo. ¿Estos ejemplos (y otros) no muestran la permeabilidad de las fronteras entre lo público y lo privado? En esta misma línea, la participación de curas, priores, jefes militares, maestros artesanos y otras autoridades laborales, así como fiscales, escribanos, jueces, etcétera, en los entuertos conyugales, extraconyugales y en las discordias paterno-filiales de sus subordinados o dependientes, no conforman un decorado secundario en la trama de relaciones humanas que examina el autor.

Por otra parte, la información que presenta el libro invita al contraste con el mundo actual. Robins nos sumerge en el pasado de Charcas para demostrarnos que algunas creencias, prácticas y costumbres tenían una singularidad, un valor y una trascendencia que no encuentran parangón con la actualidad. Es el caso de la legislación matrimonial y su relación con los estereotipos para cada integrante del grupo familiar; es el caso, igualmente, de la importancia que tuvo el honor a lo largo de la época colonial, tomando en cuenta el género y las diferencias jerárquicas, así como sus cambios en el siglo XVIII. Del mismo modo, la figura de las casas de recogimiento para las mujeres inmersas en conflictos conyugales (los beaterios y los monasterios); o la relevancia de los tribunales de justicia eclesiásticos en donde se incoaban litigios como las anulaciones y «divorcios». Y, por supuesto, está ahí el patriarcado que, en el contexto del siglo XVIII, fue puesto en tela de juicio por muchas mujeres (y por algunos ilustrados) en el sentido no de cuestionar la autoridad patriarcal, más sí de renovarla sobre la base de una mayor flexibilidad en la relación hombre-mujer, incorporando criterios de sociabilidad y racionalidad, articulados con los nuevos roles que los intelectuales ilustrados venían postulando. Este cuestionamiento, sin embargo, colisionó con las propuestas monárquicas orientadas a reforzar el patriarcado tradicional, como lo demostró la mencionada Pragmática de 1776. En suma, un contexto de crisis, un entramado complejo que, considerando variables étnicas, estamentales y de género, es el que envuelve a las personas de carne y hueso que examina el libro del profesor Robins.

Como podrá observarse, son varias las conclusiones que pueden obtenerse de este trabajo. A saber, las relaciones de pareja, la intimidad, se consiguieron a menudo infringiendo las normas civiles y eclesiásticas; por ello, el amancebamiento, los vínculos extraconyugales y los matrimonios clandestinos. Por otro lado, es interesante el desenlace al cual se arriba a partir de estas consideraciones: el desencuentro entre la normatividad y la praxis social que, expresado en estos 
hechos, se hace presente también en las promesas matrimoniales incumplidas (esponsales), la ilegitimidad, los hogares dirigidos por mujeres abandonadas y solteras, la relativa tolerancia hacia la infidelidad masculina y la presencia de curas con amantes y familia. Asimismo, el contraste entre la actitud más laxa de la Iglesia respecto del matrimonio y el papel más rígido del Estado, sobre todo desde la Pragmática Sanción, condujo, según Robins, a la intensificación de la litigación judicial en los tribunales civiles, militares y eclesiásticos. Se trató, básicamente, de castigar al infractor, destacando los juicios de nulidades y de divorcio, aunque en muchos casos la separación de las parejas era un hecho fáctico. Entre las causas más resaltantes de las querellas judiciales estuvo la violencia doméstica, la cual, pese a ser socialmente y legalmente aceptada, supuso muchas veces un exceso que fue denunciado vigorosamente.

Entre las conclusiones del libro merece destacarse, finalmente, la reflexión que el autor le brinda a la documentación contenciosa. Esta refleja la naturaleza de muchos matrimonios y sus dificultades, entre ellas lo extendido de la violencia. Pero, además, más allá del odio y el amor, el análisis de los casos estudiados y sus narrativas revela «una sociedad altamente fragmentada, de doctrinas rígidas, violenta e itinerante». Pese a que estos juicios no eran tan profusos (suponían gastos, paciencia, no siempre se conseguía lo que se buscaba, entre otras consideraciones), reflejan tendencias más amplias y son elocuentes sobre lo que dejan de manifestar: «una tendencia a negociaciones extrajudiciales (...), divorcios informales o de facto, y una sociedad donde las desviaciones de la moralidad eran comunes». A otro nivel, esta documentación retrata también la calle: la plaza, el mercado, la iglesia, la pulpería, el taller, el cajón del comerciante, todos ellos espacios donde se desenvuelven muchos protagonistas, demostrando que la movilidad social y geográfica era más fluida de lo que se piensa, incluyendo la posibilidad de que un individuo se «presente» de una u otra manera, según las circunstancias. Estas «movilidades» suponen ambigüedades identitarias que, junto a la ambigüedad teoría-realidad, se extendieron a los cimientos patriarcales permitiendo, en tal sentido, que algunas mujeres pudieran, hasta cierto punto, eludir el dominio masculino, tal es el caso de las viudas.

A manera de corolario, se hace necesario meditar sobre algunos comentarios y resoluciones del autor. En este sentido, es un acierto la distinción que establece entre la percepción del honor anterior al siglo XVIII del que se desarrolló en este siglo, que involucró a más segmentos sociales, incorporando criterios de «riqueza y honestidad» antes que elementos de «raza y orígenes nobles». Por otro lado, Robins diferencia entre recogimiento y depósito, siendo el primero efectuado en un monasterio o en un «orfelinato sacro» (beaterio), suponiendo confinamiento o reclusión, en tanto el depósito se llevaba a cabo en una casa respetable. Acota que no era lo mismo estar en una casa que en un beaterio o monasterio y que en estos 
últimos lugares podían sufrirse penurias. A este respecto, son interesantes tanto la distinción establecida, como la variedad de situaciones y experiencias que una mujer podía experimentar en estas condiciones. Habría que aclarar, sin embargo, que en la ciudad de Lima, a diferencia de Charcas, los depósitos de las mujeres con conflictos familiares que se judicializaban, se efectuaron preferentemente en los beaterios y solo, eventualmente, en la residencia de un vecino notable, el cual, inclusive, podía ser un familiar.

Asimismo, es un aporte significativo mencionar que las disputas conyugales que se ventilaban en los tribunales podían incoarse en cualquiera de los tres fueros: el civil, el eclesiástico y el militar; y que se podía litigar en varios frentes a la vez. No obstante, considero que este análisis presenta una cierta rigidez al afirmarse que causales como el abuso conyugal, la infidelidad, la falta de manutención, entre otras, se trataban en los juzgados civiles. En realidad, estos asuntos dependían también de los demandantes - generalmente mujeres-, quienes decidían a cuál judicatura recurrir, según también lo que deseaban: separación de cuerpos, anulación, castigo, etcétera; por lo demás, habría que tomar en cuenta también a los jefes laborales, quienes podían igualmente terciar en los entuertos maritales.

Del mismo modo, son interesantes las alusiones a la situación de las viudas. Partiendo de la opinión generalizada acerca de la debilitada condición legal de las mujeres, Robins sostiene que aquellas estaban mejor posicionadas que las mujeres casadas. Es cierto. Empero, tal afirmación requiere de matices pues los casos de viudas estudiadas para México colonial y también para Lima, demuestran que la impronta patriarcal pesaba. En estos lugares, algunas de ellas llegaron a lamentarse por no haber contado con el apoyo de una pareja. La viudez, por otra parte, no siempre fue una condición definitiva y muchas viudas fueron impulsadas a buscar consorte por la necesidad y la presión social.

Igualmente, son reveladoras las digresiones relativas al adulterio masculino. Robins señala al respecto que la sociedad charquense fue más indulgente con los varones cuando se trataba de concubinato o infidelidad. Además, según la legislación colonial, el adulterio del marido no era ilegal, salvo excepciones. Sin embargo, de acuerdo con las leyes civiles, un hombre podía matar a su esposa adúltera. Técnicamente es correcto, pero como aconteció en otros lugares de Hispanoamérica, ello no se cumplió, al menos legalmente, y los casos de infidelidad femenina abundaron en Charcas, según la documentación contenciosa. No obstante, no se aclara cuántos de esos casos estuvieron debidamente fundados o fueron producto de la fantasía y los celos de los maridos.

Los abundantes comentarios sobre la violencia conyugal constituyen, además, una buena síntesis de lo que acontecía también en otros lugares. Ellos nos acercan a las múltiples dimensiones de la violencia que tuvieron como protagonistas centrales 
a las mujeres, pues el abuso doméstico era común y socialmente aceptado, siendo ciertamente las mujeres la principales víctimas de la misma. El texto abunda en información cualitativa, aludiendo a sus causales, frecuencia, prevalencia y naturaleza del maltrato conyugal, incluyendo tópicos conexos como el de la violación.

El magnífico libro del profesor Robins, sin lugar a dudas, invita a mayores reflexiones y no es valioso solo por lo que informa, sino también por lo que deja traslucir, así como por los evidentes contrastes con la realidad presente. 